\title{
Development of a Prototype Uninterrupted Electrical Power Supply System using Compressed Air Storage from Renewable Energy Resources
}

\author{
Gul Rukh ${ }^{1}$ Amjadullah Khattak ${ }^{1}$ \\ RECEIVED ON 26.12.2018, ～ACCEPTED ON 26.07.2019
}

\begin{abstract}
Over the last two decades, Pakistan's energy demand has grown exponentially with very diminutive measures taken by the government to fulfill the needs. The large power plant projects are cumbersome, take years to be completed and require plenty of time to get fully operational. The idea of distributed generation works well in this case. Renewable energy comes well into play when we talk about distributed generation but the dependability of renewable energy resources on back-up such as batteries makes them unappealing. The objective of this paper is to practically implement a backup for the renewable energy resources using a mechanical storage such as CAES (Compressed Air Energy System). The proposed model is a composite technology, which comprises of EES (Electrical Energy Storage) and electrical power supply system. Solar energy driven compressor is used to compress the air in a storage tank, which is used on demand to drive the generator coupled air turbine. The fact that the developed system is solar powered, no other fuel is used with air and it uses mechanical storage instead of conventional storage like batteries, which makes the developed prototype system efficient, economical and durable as compared to the existing CAES. This paper focuses on the thermodynamic investigation, design and finally implementing a prototype CAES for a small load as an un-interrupted power supply system.
\end{abstract}

Key Words: $\quad$ Sustainable Power Source, Electrical Energy Storage, Energy Sources, Compressed Air Energy Storage.

\section{INTRODUCTION}

$\mathrm{E}$ lectricity is considered as a backbone of any economy and most dynamic gadget of socioeconomic progress of a country. It is the key concern of every government to ensure electricity access to the growing industries and to the poor parts of the population. Pakistan's electrical power supply against the demand has remained an unresolved matter since many years. Despite all the measures taken by the Pakistani government, only $67 \%$ of its population has an access to electricity. The shortfall ranges from 4000-5000MW. The situation where demand surpasses the supply, is dealt with load shedding through power cut down. As a result, one third of the total population has to face a load shedding of 12-16 hours [1].

Most of the residential consumer, use either one or the other of these resources during blackout i.e. UPS (Uninterrupted Power Supply), Gas (Methane) or petrol generators, solar panels PV (Photovoltaic) and very rarely wind turbine [2-3]. Since the electricity load shedding sometimes increases more than 3 hours at a time, most of the population uses either gas or petrol generators as backup. This brings the consumer under economic pressures as he has to pay the bills for electricity as well as gas and additional charges of petrol as well.

\footnotetext{
${ }^{1}$ Department of Electrical Engineering, University of Engineering and Technology, Peshawar, Pakistan Email: engrgul@uetpeshawar.edu.pk (Corresponding Author), amjad67@gmail.com
}

This is an open access article published by Mehran University of Engineering and Technology, Jamshoro under CC BY 4.0 International License. 
-With increasing population and inflation in the prices of electricity from conventional sources of energy, the world is moving towards distributed generation from renewable means [4]. According to the Alternative Development Energy Board, Pakistan has a capability to produce 3.34 million megawatt of clean energy with solar a producing big share [5].

Electricity generation from Renewable energy resources is unpredictable because of its intermittent nature. The needs of electrical energy storage arise from the strong variation in load and the intermittent availability of sustainable sources of energy (like solar and wind) [6-7]. The sustainable power source has an extraordinary potential to produce power as it is rich in nature and causes no mischief to the nature.

A techno-economic study shows the presence of some barriers to the bulk production of electricity from these alternative sources of energy. The major cause of unreliability of such means is its intermittent nature. The unpredictable nature of renewable energies compels the operators and generators of electricity to develop means to store them $[1,4-5]$.

The performance, reliability and life of renewable energy systems critically rely on backup in the form of EES due to their sporadic nature. Available EES devices have issues related to their life, performance, site dependability and environmental conditions.

The alternative solution can be CAES, which is worth exploring. This is not a new technology and two plants, one in Huntorf, Germany and one in McIntosh, Alabama are already in operation. In such plants, air is compressed by a compressor during the off peak period in the underground caverns or sometimes large storage tanks above ground [8]. During the period of peak load demand, the air from the cavern is released, to drive the expansion turbine which in turn drive the generator to produce electricity [5-6]. CAES plants have some round trip efficacies of 50\% [9]. Such plant follows a thermodynamic process such as adiabatic [10]. The paper is sorted out as take after: Introduction, Problem Formulation and System Modeling, Related Theories \& System Modeling, Results, Conclusions and References.

\section{PROBLEM FORMULATION AND SYSTEM MODELING}

The major drawbacks of the existing CAES plants are the utilization of methane gas $\left(\mathrm{CH}_{4}\right)$ with the expanded air and its low round trip efficiency. The round trip efficiency can be improved by using AA-CAES
(Advanced Adiabatic Compressed Air Energy System) where heat of compression is utilized to reheat the air before expanding through air turbine [11-12]. The usage of AA-CAES has shown a tremendous increase in efficiency of about $70-75 \%$. Conversely, no measures have been taken to make the system cost-effective, because the use of $\mathrm{CH}_{4}$ also makes it uneconomical [13]. Annually Pakistan consumes approximately 1559 billion cubic feet of natural gas. Currently, Pakistan is producing $8375 \mathrm{MW}$ of electricity from CNG (Compressed Natural Gas) and 3600 MW from LNG (Liquefied Natural Gas). The cost of electricity generation using gas stood at PAKRS 5.86 per kilowatt hour, according to NEPRA (National Electric Power Regulatory Authority) by March 2016. The share of gas among other fuels for electricity production has recently raised to about $33.13 \%$. The amplified use of CNG by different types of consumers and also for electrical power production has also compelled the government to import gas but has failed to do so at lower prices [14]. One solution to the a fore stated problems can be the elimination of $\mathrm{CH}_{4}$ from the CAES operated power plant [15]. Meanwhile, natural gas is a fossil fuel and its use pollutes the environment, and the rapid forthcoming situation is that we can no longer let go the problem or delay the solution.

The source to get a compressed air is a compressor. There are different categories of compressors depending upon the working principle and working conditions [16]. When we study the life cycle cost of the compressor, it is realized that the major cost share among its initial, maintenance and running/energy cost is actually its electrical energy expense that it consumes as shown in Fig. 1 [15].

If somehow we are able to reduce its energy cost then it would be easy to reduce the total cost of the compressor [17].

The objective of this research is to design and implement a prototype CAES for a small load as a UPS system for homes. The development of an alternative solution to classical batteries is the main motivation of the current research project.

In the proposed system model of CAES, no methane gas is used and system is flexible enough to utilize power either from grid or from sustainable PV module to produce electricity on demand or during black out [18-19]. The system is essentially a UPS system, which utilizes unconventional mechanical storage like CAES [19]. This system is different from the UPS available in the market in the sense that it does not use batteries as its backup. Batteries are unreliable; have Mehran University Research Journal of Engineering and Technology, Vol. 39, No. 2, April 2020 [p-ISSN: 0254-7821, e-ISSN: 2413-7219] 


\section{Compressor lifecycle cost breakdown}

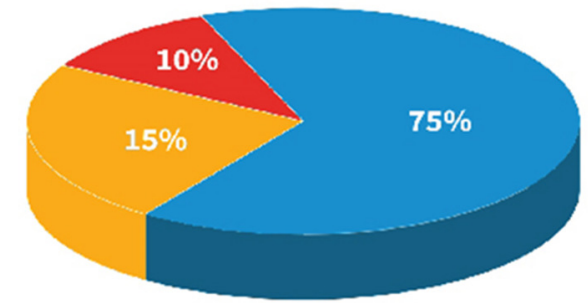

- MAINTENANCE COST " COMPRESSOR COST = ENERGY COST

\section{FIG. 1. COMPRESSOR LIFECYCLE COST} BREAKDOWN

shorter life span and are toxic in nature. The vitality stockpiling framework range of applications is shown in Fig. 2 [6].

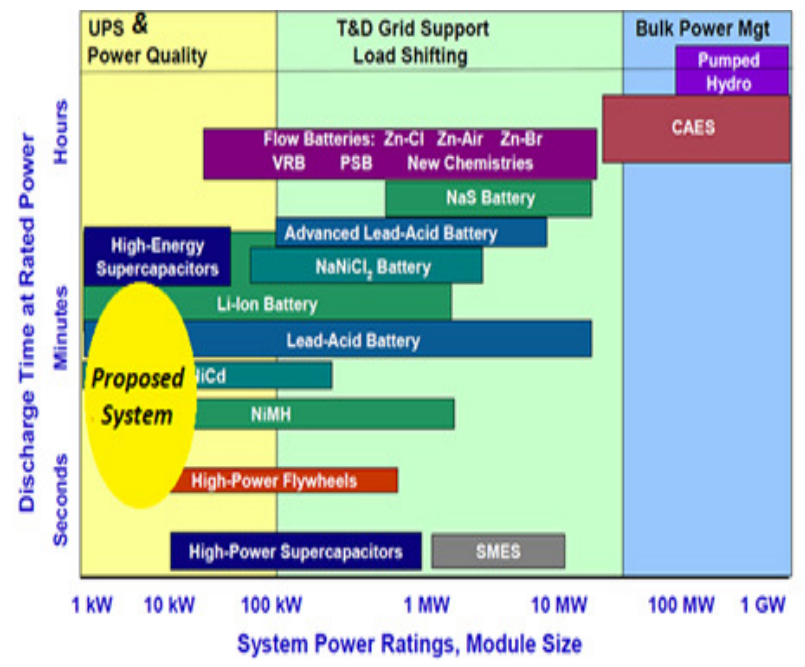

FIG. 2. ENERGY STORAGE SYSTEMS APPLICATION RANGE

The sustainable power source for controlling UPS on the principle of CAES is proposed and shown in Fig. 3 [21].

This hybrid framework uses the simple law of thermodynamics such as compression and expansion to generate electricity to be used by the small load [2223]. A 2HP (Horse Power) reciprocating compressor takes power from the clean solar energy and compresses the air from the surrounding in an air cylinder [24-25]. Since a prototype is developed, low power rated and low scale components are considered which makes the system economical as well. The compressed air from the cylinder is used on consumer demand to drive the small electrical load. The paper emphasizes on the thermodynamic model, efficiency, and time of discharge in collaboration with photovoltaic source.

\section{RELATED THEORIES AND SYSTEM MODEL}

The basic idea of converting the energy available from the sustainable source like Sun to produce electricity is shown in Fig.3. The formulated model is a composite innovation, in which the power available from PV panels can either be directly supplied to the loads through converter or be used to compress the air through air compressor to be stored in cylinders as a backup [26]. The proposed layout represents a UPS system, with cylinders replacing batteries. The backup in the form of air cylinders can be used on demand or when the solar energy is not available to drive an energy efficient air turbine. The turbine is coupled with a generator, which finally changes the mechanical power from the turbine to electrical energy to supply a small load [27].

In Fig.4, compressor is used to convert two parameters of electrical energy such as Torque (T) and speed of the shaft $(\mathrm{N})$ to the two parameters of energy contained in the air that is: pressure of air $(\mathrm{P})$ and discharge $(\mathrm{Q})$ [28]. It is clear from the energy flow diagram that the converse of the above process is done by the air turbine where $\mathrm{P}$ and $\mathrm{Q}$ are again converted to the electrical parameters to drive the generator [29]. The complete investigation of solar energy conversion and thermodynamics involved in compression and rarefaction of air is discussed in the following sections.

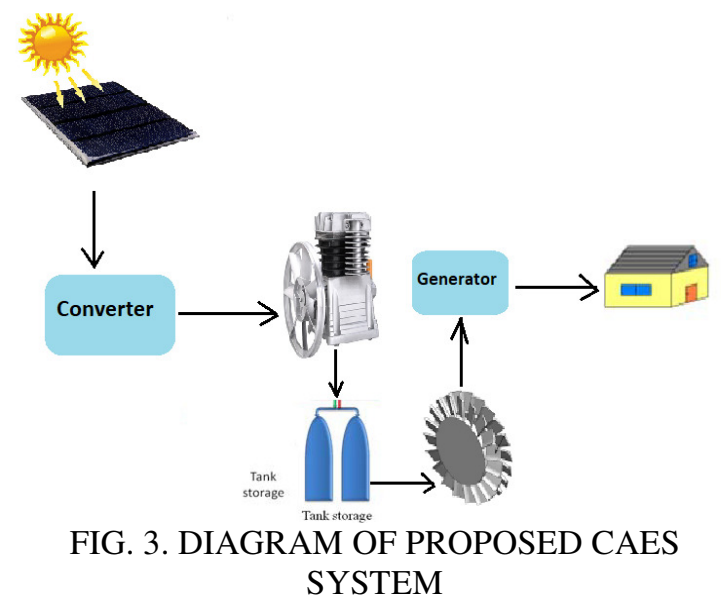
3.1 Modelling of Conversion of the Power
using Solar 
Pakistan, located in South-east Asia, is blessed with plenty of sunshine by nature and has diverse geographical features. For an average value of 2050 $\mathrm{kWh} / \mathrm{m}^{2}$, the estimated potential for solar energy in Pakistan can be as high as 542 TWh [30]. The average sunshine in Peshawar city of Pakistan, ranges from 1215 hours during peak summer season and 6-7 hours ring peak winter season. For PV design the data is shown in Table 1.

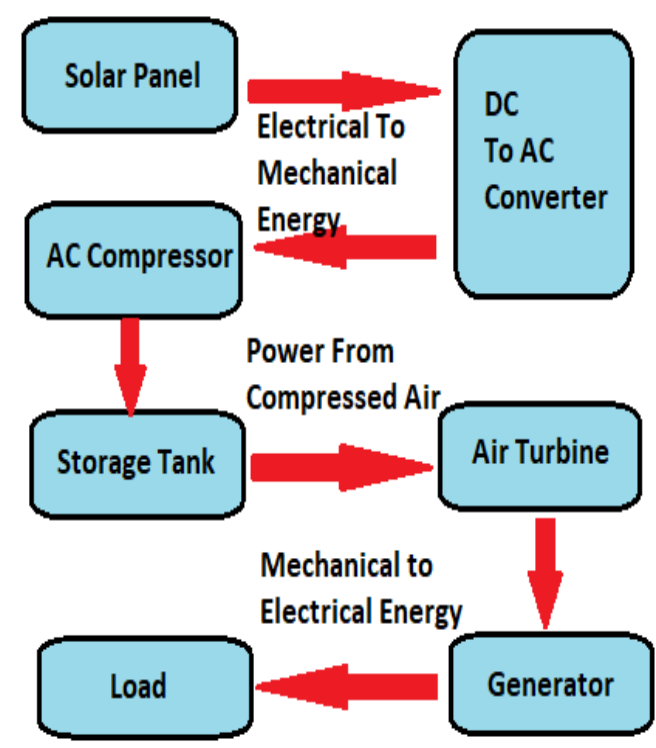

FIG. 4. ENERGY FLOW DIAGRAM

\begin{tabular}{|l|}
\hline TABLE 1: DATA AVAILABLE FOR PV \\
DESIGN \\
\hline Power Requirement: $2 \mathrm{~kW}$ \\
\hline Average effective daily sunshine: 6 hours \\
\hline $\begin{array}{l}\text { Average solar irradiance: } 2000 \mathrm{kWh} / \text { day or } \\
250 \mathrm{~W} / \mathrm{m}^{2}\end{array}$ \\
\hline Solar Power Density: $250 \mathrm{~W} / \mathrm{m}^{2}$ \\
\hline
\end{tabular}

A solar power system is designed in helioscope software for the above design requirement, to compress air through compressor and store it for the specified number of load shedding hours during the effective sunshine hours [31-33].

However, knowing the average insolation at a particular location, it is simple to estimate the total energy received over the course of time. The delivery of sun energy $\mathrm{ES}$ in $\mathrm{kWh}$ is given as:

$\mathrm{E}_{\mathrm{s}}=\mathrm{K}_{\mathrm{s}} \mathrm{H}_{\mathrm{s}} \mathrm{P}_{\mathrm{m}}$

where $K_{s}$ is the performance ratio of the system whose values ranges from 0.5-0.6 for standalone plant [16]. $\mathrm{H}_{\mathrm{s}}=$ Number of peak sun hours per day
$\mathrm{P}_{\mathrm{m}}=$ Peak power $\left(1 \mathrm{~kW} / \mathrm{m}^{2}\right.$ solar irradiation $)$

$\mathrm{P}_{\mathrm{m}}$ depends on the area (A) and efficiency $(\mathrm{\eta})$

$E_{s}=A \times \eta \times H_{s} \times K_{s}$

$\frac{E_{S}}{t}=P_{S}=\frac{A \times \eta \times H_{S} \times K_{S}}{T}$

The cell junction temperature is $25^{\circ} \mathrm{C}$ at air mass ratio of 1.5. With increasing temperature, the short-circuit current of the cell increases, as the open-circuit voltage decreases. The decrease in power $\mathrm{P}$ with temperature is given by an expression:

$P=P_{0}[1+(\alpha-\beta) \Delta T]$

where $\mathrm{P}_{\mathrm{o}}=$ initial power. Whereas for a single crystal silicon cell, the value of $\alpha$ and $\beta$ is $\alpha=500 \mu \frac{\mathrm{m}}{{ }^{\circ} \mathrm{C}}$ and $\beta=5000 \mu \mathrm{m} /{ }^{\circ} \mathrm{C}$ and $\Delta \mathrm{T}$ is change in temperature. The inverter which is the vital part of the PV system is carefully chosen from the locally available inverters in market for domestic and commercial purposes. Thus an inverter with the following specifications was chosen.

Rating: $4 \mathrm{~kW}$

Input: $12 / 24$ VDC ports

Output: Sine wave, $220 \pm 10 \mathrm{VAC}, 50 \mathrm{~Hz}$.

Feature: Hybrid: Off-grid and Grid-tied operation

Additional feature: Voltage stabilization

\subsection{Thermodynamics Conversion of Compressed Air}

A compressor is selected from the available types in the market according to the amount of electrical energy available in excess from the renewable energy such as solar power plant to be used to compress air [33-34]. Fig. 5 shows the compressor selection criteria.

The compressed air is utilized afterward as a part of the working procedure via air expander or turbine [35]. There can three ways of compression and expansion of air from thermodynamic perspective. Hence the CAES system can function under a polytrophic, isothermal or by an adiabatic process [18].

However, in reality, it is hard to accomplish both isothermal and adiabatic processes and for the same reason a study of polytrophic compression and expansion has been carried out in this work [37-38]. Air is considered as an ideal gas, in which the specific heat is constant and utilizes a perfect gas equation, which relates $\mathrm{P}$ (Pressure), $\mathrm{V}$ (Volume) and $\mathrm{T}$ (Temperature) given by the impression $\mathrm{PV}=\mathrm{nRT}, \mathrm{R}$

Mehran University Research Journal of Engineering and Technology, Vol. 39, No. 2, April 2020 [p-ISSN: 0254-7821, e-ISSN: 2413-7219] 
is the gas constant and $\mathrm{n}$ is the quantity of mole $[2,4,6]$. The procedure for the conversion of compressed air into polytrophic process is given in the Equation (5).

$\mathrm{W}=\left(\frac{\gamma}{\gamma-1}\right) \times \mathrm{P} 1 \mathrm{~V} 1\left[\left(\frac{\mathrm{P} 2}{\mathrm{P} 1}\right)^{\frac{\gamma-1}{\gamma}}-1\right]$

where $\mathrm{V} 1, \mathrm{~V} 2, \mathrm{P} 1$ and $\mathrm{P} 2$ are the volume and pressure of the initial and final state respectively. However, work per unit time can be considered as power $(\mathrm{Pc}=$ $\mathrm{W} / \mathrm{T})$ and volume per unit time as discharge $\mathrm{Q}(\mathrm{Q}=$ $\mathrm{V} / \mathrm{T})$. The power of compression can be calculated as: $\mathrm{P}_{\mathrm{c}}=\left(\frac{\gamma}{\gamma-1}\right) \times \mathrm{P}_{1} \mathrm{Q}\left[\left(\frac{\mathrm{P} 2}{\mathrm{P} 1}\right)^{\frac{\gamma-1}{\gamma}}-1\right]$

where the ratio of the specific heat transfer is represented by $\gamma, \gamma=\mathrm{C}_{\mathrm{p}} / \mathrm{C}_{\mathrm{v}},\left(\mathrm{P}_{2} / \mathrm{P}_{1}\right)$ is the ratio of the compression [6, 23-24].

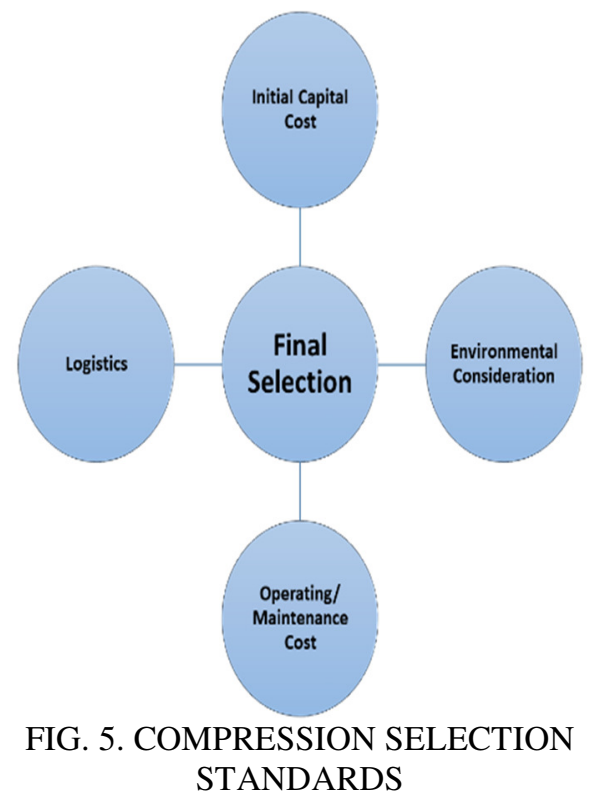

\subsection{Solar Power Driven CAES}

The wind stream in the compressed form is driven by the solar vitality which is given in Equation (7) [3940]

$\mathrm{Q}=\frac{\mathrm{P}_{\mathrm{S}}}{\left(\frac{\gamma}{\gamma-1} \times \mathrm{P}_{1}\left[\left(\frac{\mathrm{P}_{2}}{\mathrm{P}_{1}}\right)^{\frac{\gamma-1}{\gamma}}-1\right]\right)}$

Power directly depends on the air flow and pressure which changes with the energy from the solar panel [41-42]. Different scenarios are taken in which turbine runs on variable and fixed air pressure [43]. The overall efficiency of the system can be calculated by Equation (8) as [44]:

$\eta=\frac{P_{c}}{P_{s}}=\frac{\left(\frac{\gamma}{\gamma-1}\right) \times P_{1} Q\left[\left(\frac{P 2}{P 1}\right)^{\frac{\gamma-1}{\gamma}}-1\right] \times \eta \mathrm{c}}{\text { Ps }}$

where $\eta_{c}$ is the efficiency of the compressor and compact air generator, separately.

\section{RESULTS}

In modeling, our main aim is to analyze the thermodynamics of CAES to compress air energy from renewable source. A relationship between output pressure from the air tank and the efficiency of the air turbine is derived Thermodynamic mimics are under the conditions given as: temperature $\mathrm{T}=$ $293 \mathrm{~K}$ and $\gamma=1.3$. Furthermore, atmospheric pressure is equal to 1 atm.

After carefully selecting all the components, the final version of the model shown is in Fig. 6.

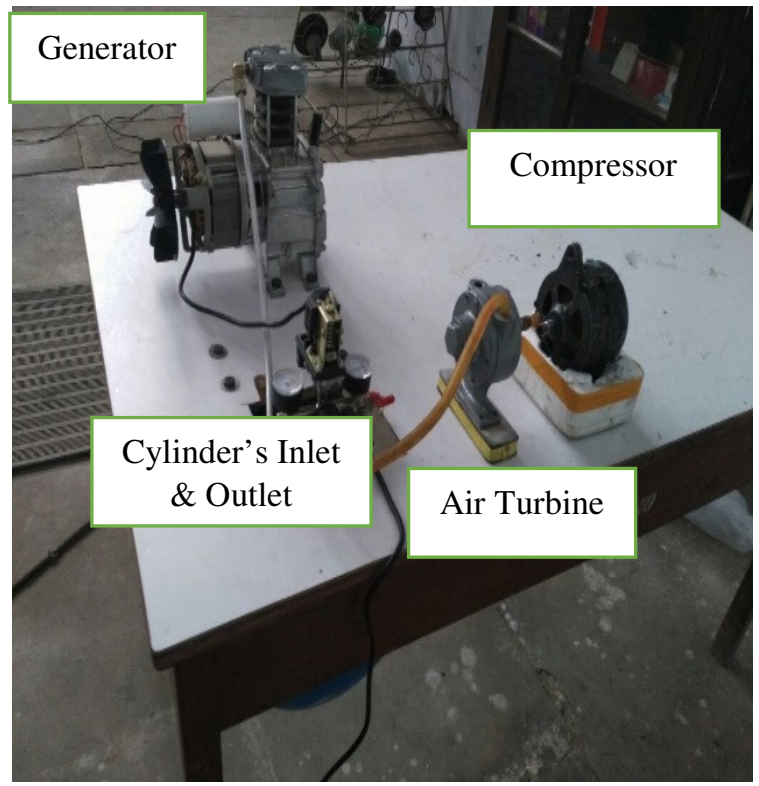

\section{FIG.6 MODEL OF UPS USING CAES FROM PV SOURCE}

The proposed model follows the same charge and discharge time, as the plant in Huntorf being 2:1. Standardization is necessary and beneficial both from safety and environmental aspects. The ISO (International Organization for Standardization) has developed some standards for Compressors (EN 1012- 
1) and simple pressure vessels (EU Directive 87/404/EC). Since CAES is a new technology specifically in Pakistan, no national standards are developed for this system. However, there are standards for air storage and the name plate ratings of the pressure vessel have been followed in present work. Moreover, the system is automatic and compressor stops when the name plate ratings (that is maximum $120 \mathrm{psi}$ ) is reached.

The output of air turbine is calculated in a way which entirely depends upon discharge per meter cube from the air tank. Increasing the capacity of the tank can increase the discharge $(\mathrm{Q})$, air ejection time and hence the load can be supplied with electric power for maximum time. CAES operates with reciprocating air compressor of $220 \mathrm{~V}$ and $2 \mathrm{hp}$ ratings to fill the air tank that has a capacity of 50 liters of air. The continuous rating of all the equipment is shown in Table 2.

\begin{tabular}{|c|c|c|c|}
\hline \multicolumn{4}{|c|}{ TABLE 2. RATINGS OF MAIN COMPONENT } \\
\hline No. & Equipment & Type & Ratings \\
\hline 1. & Compressor & $\begin{array}{c}\text { Reciprocating } \\
\text { single stage }\end{array}$ & $2 \mathrm{Hp}$ \\
\hline 2. & Air Turbine & $\begin{array}{c}\text { Pneumatic } \\
\text { motor }\end{array}$ & $\begin{array}{c}0.93 \mathrm{Hp} \\
3000 \mathrm{rpm}\end{array}$ \\
\hline 3. & $\begin{array}{c}\text { Storage } \\
\text { Tank }\end{array}$ & Cylinder & 50 liter \\
\hline
\end{tabular}

From Fig.7, it can be observed that the system being small can operate the pneumatic motor for a minimum time of 1 min, whereas the charging time of air tank being recorded as $2 \mathrm{~min}$.

From Table 3, it can be seen that the smaller the output pressure or the smaller the discharge $\mathrm{Q}$, the greater will be the time in which the tank/cylinder is discharged. This also shows that increasing the capacity of the air tank could increase the time for which CAES operates as UPS.

As shown in Fig. 8, there is an inverse relationship between pressure and time of discharge.

The speed of the air turbine depends upon the volume discharge and the pressure of air from the storage tank. Initially at $120 \mathrm{psi}$ the speed of the air turbine is maximum i.e. $3306 \mathrm{rpm}$ and as the pressure decreases the speed of air turbine decreases until at $45 \mathrm{psi}$ the speed decreases to $1635 \mathrm{rpm}$. The speed verses pressure relationship can be observed from Fig. 9. At higher pressure of $120 \mathrm{psi}$, the speed of the turbine is likewise maximum. It can be seen that, as the pressure of air from tank decreases the speed of air turbine decreases for some time initially. However, between 90-55psi the speed of air turbine remains almost constant at about 2600rpm. Below 55 psi, there is a rapid decrease in speed with the decrease in pressure and the relationship is almost linear. The magnitude of generated voltage depends upon the speed of air turbine driving it as well as the ratings of the generator coupled.

\begin{tabular}{|c|c|c|}
\hline \multicolumn{3}{|c|}{ TABLE 3. TIME OF DISCHARGE OF } \\
CYLINDER AT DIFFERENT PRESSURES \\
\hline No. & $\begin{array}{c}\text { Adjustable } \\
\text { Pressure (psi) }\end{array}$ & $\begin{array}{c}\text { Time of Discharge of } \\
\text { Tank (sec) }\end{array}$ \\
\hline 1. & 120 & 40 \\
\hline 2. & 90 & 44 \\
\hline 3. & 60 & 75 \\
\hline 4. & 45 & 241 \\
\hline 5. & 30 & $\begin{array}{c}\text { No discharge is } \\
\text { observed at 30psi }\end{array}$ \\
\hline
\end{tabular}

\section{CONCLUSION}

This study is carried out to scrutinize the already developed models of CAES, which utilize the natural gas as a part of fuel and are burnt together with air to be supplied to the expansion turbine coupled with generator whose overall efficiency is as low as $50 \%$. The proposed model is developed to be used on small scale basis to supply a small load. In this case a pneumatic motor is used as an air turbine to drive a small generator. The system efficiency is still low but very economical. The system performance can be increased by selecting an air turbine of the jet propeller type whose efficiency and speed is more than this simple air turbine. The system can be made more energy efficient by selecting a DC compressor since the $\mathrm{kWh}$ (kilowatt hour) consumption of DC compressor is almost half the AC compressor. On the other hand, it would be much easy to power a DC Compressor from solar panel. One more advantage would be the exclusion of inverter, and we can use a simple DC-DC converter. The above alternatives can increase the efficiency of the system up to $85 \%$. Since the output of the air turbine also depends upon the discharge and hence the capacity of air available, the productivity can be improved by increasing the capacity of tank used. The output of renewable energies is highly unstable and needs flexible energy storage as CAES. The problem faced by such mechanical storage is that it has to compete with much mature storage devices available in the market. 


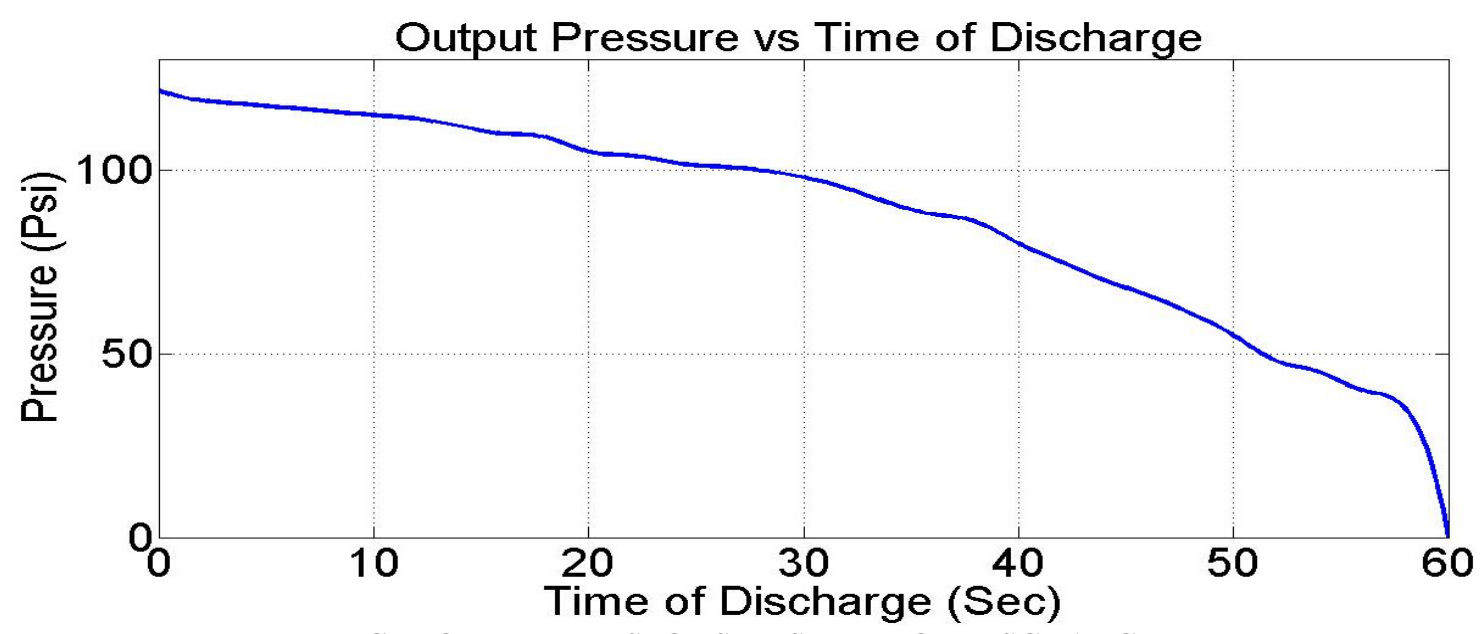

FIG 7: OUTPUT RESPONSE VS TIME OF DISCHARGE

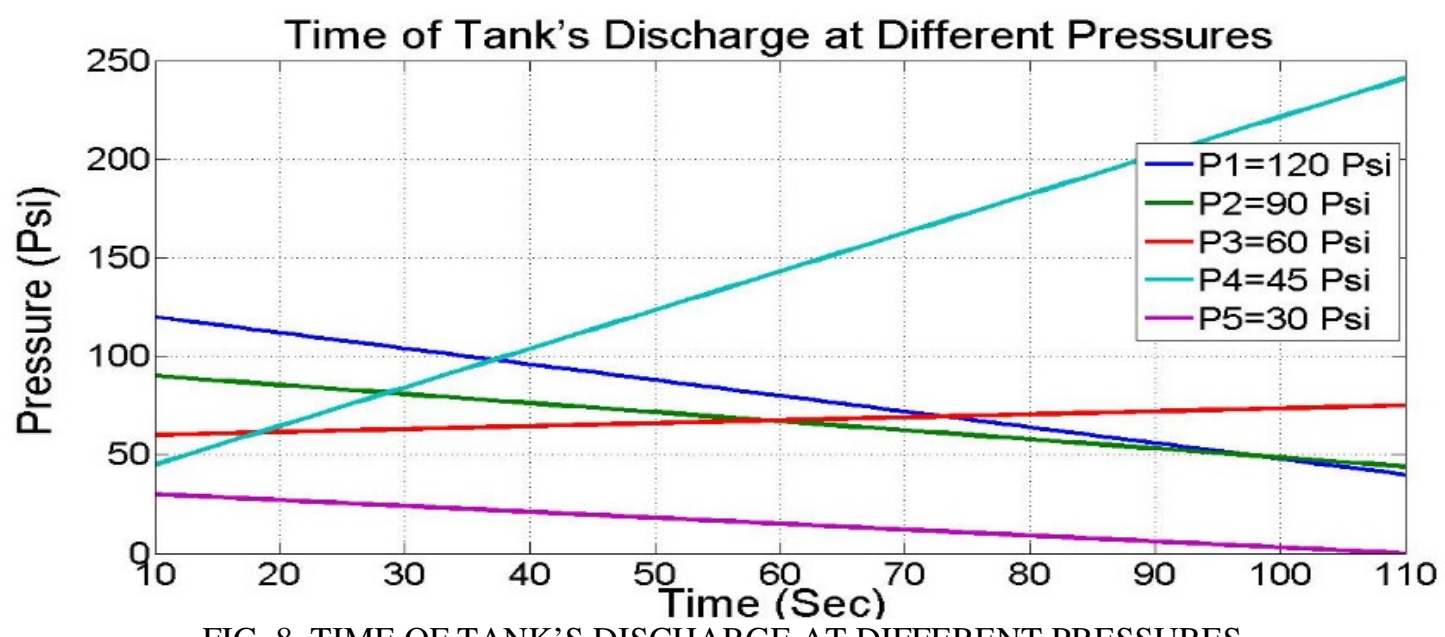

FIG. 8. TIME OF TANK'S DISCHARGE AT DIFFERENT PRESSURES

\section{Pressure vs Speed Curve}

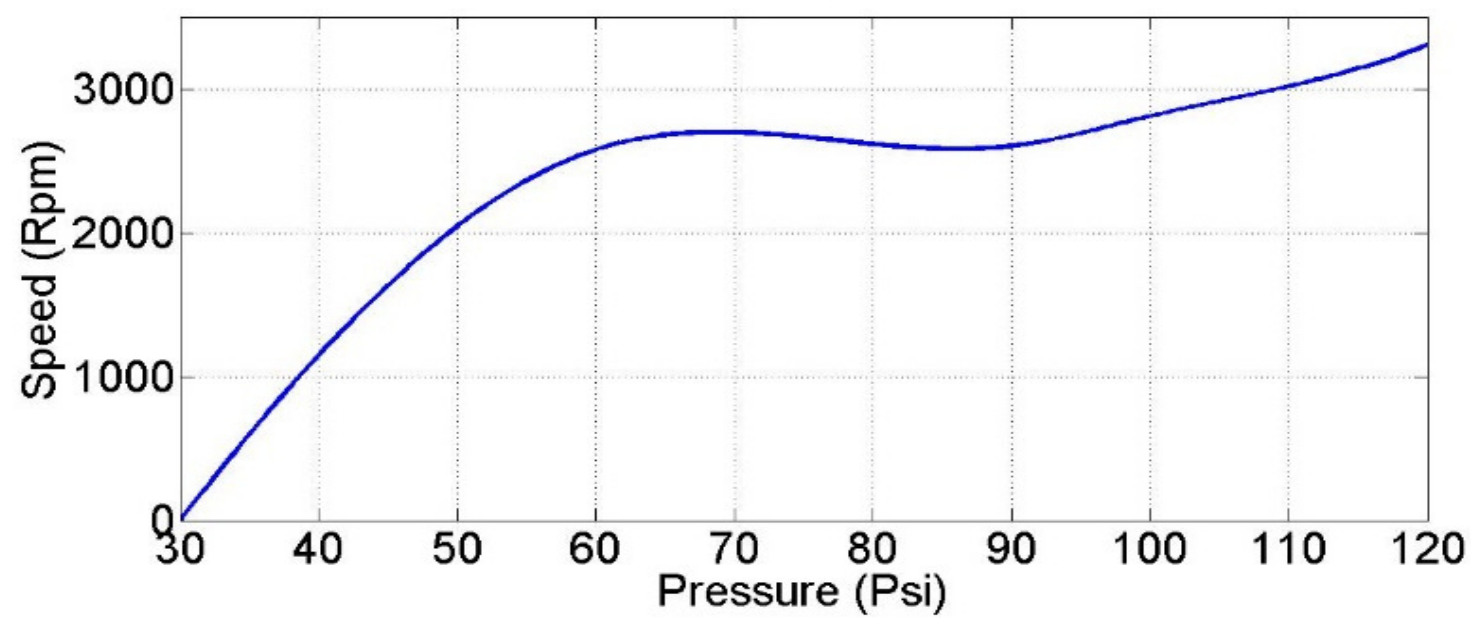

FIG.9 PRESSURE VS SPEED CURVE 


\section{ACKNOWLEDGMENT}

The first author acknowledges Prof. Dr. Muhammad Naeem Arbab and Prof. Dr. Amjad Ullah Khattak, Department of Electrical Engineering, University of Engineering \& Technology, Peshawar, Pakistan, for their administrative and technical support.

\section{REFERENCES}

[1] "An Overview of Electricity Sector in Pakistan", Islamabad Chamber of Commerce \& Industry Chamber House: Aiwan-e-Sanato-Tijarat Road, Mauve Area, Sector G-8/1, Islamabad.

[2] B. Tamimi, C. Cañizares and K. Bhattacharya, "System Stability Impact of Large-Scale and Distributed Solar Photovoltaic Generation: The Case of Ontario, Canada" IEEE Transactions on Sustainable Energy, Vol. 4, no. 3, pp. 680688, July 2013.

[3] Awan M.M.A. and Awan F.G., "Improvement of Maximum Power Point Tracking Perturb and Observe Algorithm for a Standalone Solar Photovoltaic System", Mehran University Research Journal of Engineering and Technology, Vol. 36, No. 3, July, 2017.

[4] Lund H. and Salgi G., "The role of compressed air energy storage (CAES) in future sustainable energy systems", Energy Conversion and Management, Vol. 50, Issue 5, Pages 1172-1179, May 2009.

[5] Narejo G.B., Azeem F., and Zardari S., "An Energy Policy Analysis and Proposed Remedial Actions to Reduce Energy Crises in Pakistan", Mehran University Research Journal of Engineering and Technology, Vol. 36, No. 2, April, 2017.

[6] Valentin A. Boicea, "Energy Storage Technologies: The Past and the Present", Proceedings of the IEEE, Vol. 102, No. 11, pg. 1777-1794, November 2014.

[7] Kumar D., Memon R.A., Memon A.G., Tunio I.A., and Junejo A., "Impact of Auxiliary Equipments' Consumption on Electricity Generation Cost in Selected Power Plants of Pakistan", Mehran University Research Journal of Engineering and Technology, Vol. 36, No. 2, April, 2017.

[8] Saidur R., Rahim N.A. and Hasanuzzaman M., "A review on compressed-air energy use and energy savings", Renewable and
Sustainable Energy Reviews, Vol. 14, Issue 4, Pages 1135-1153, May 2010.

[9] Gheiratmand A., Ayoubi E. and Sarlak M., "Optimal Operation of Micro-Grid in Presence of Renewable Resources and Compressed Air Energy Storage", 22nd Electrical Power Distribution Conference, Semnan, Iran, pg.131-136, April 2017.

[10] Diekerhof M., Hecker S. and Monti A., "Modeling and Optimization of Industrial Compressed-Air Energy Systems for Demand Response", 2016 IEEE International Energy Conference (ENERGYCON), Leuven, pp. 1-6, 2016.

[11] Javied T., Kimmig F., and Franke J., "Demand Based Dimensioning of Compressed Air Systems for Energy Optimization and Flexibility", 4th International Conference on Control, Automation and Robotics, pp. 492-497, 2018.

[12] Krupke C., Wang J., Clarke J. and Luo X., "Modeling and Experimental Study of a Wind Turbine System in Hybrid Connection with Compressed Air Energy Storage," IEEE Transactions on Energy Conversion, Vol. 32, no. 1, pp. 137-145, March 2017.

[13] Ping J., Zhen-Jia Z. and Hai-Jian L.V., "Optimal Load Tracking Control of Expansion Generator with Super Capacitor in Compressed Air Energy Storage System", Proceedings of the 35th Chinese Control Conference, pg.8754-8758, July 27-29, 2016, Chengdu, China.

[14] Jílek R., Gurecký J., Rusnok S. and Sobota P., "Electricity storage systems using compressed air," 2015 16th International Scientific Conference on Electric Power Engineering (EPE), Kouty nad Desnou, 2015, pp. 453-458.

[15] Vermeulen J., Cilliers C. and Marais J. H., "Cost-effective compressor control to reduce oversupply of compressed air," 2017 International Conference on the Industrial and Commercial Use of Energy (ICUE), Cape Town, 2017, pp. 1-7.

[16] Bhattarai S. and Rajesh K. "Reliability and Environmental Benefits with Market Operation of Compressed Air Energy Storage in a Wind Integrated Power System", pp. 16. 2018.

[17] Ansari O.A., Bhattarai S., Karki R., and Chung C. Y., "Reliability Evaluation of Bulk Power System Considering Compressed Air Energy Storage", IEEE Electrical Power and 
Energy Conference (CPEC), 10.1109/EPEC.2017.8286234.

[18] Chaaran A, Narendhar R and Kerthkeyan D, "Advanced Adiabatic Compressed Air energy Storage", 4th International Conference on Electrical Energy Systems, pg. 737-741, 2018.

[19] Rublack L., Warweg O., Bretschneider P., Freund S. and Bieber M., "Sensitivity Analysis of Adiabatic Compressed Air Energy Storage”, pp. 1-6, 2016.

[20] Vongmanee V., "The renewable energy applications for uninterruptible power supply based on compressed air energy storage system," 2009 IEEE Symposium on Industrial Electronics \& Applications, Kuala Lumpur, pp. 827-830, 2009.

[21] Rogers A., Henderson A., Wang X. and Negnevitsky M., "Compressed air energy storage: Thermodynamic and economic review," 2014 IEEE PES General Meeting, Conference \& Exposition, National Harbor, MD, pp. 1-5, 2014.

[22] Ciocan A., Tazerout M., Ciocan A., Ciocan A., Prisecaru T. and Durastanti J-F, "Thermodynamic evaluation for a small scale compressed air energy storage system by integrating renewable energy sources", 4th International Conference on Renewable Energy Research and Applications, Palermo, Italy, pg. 455-460, Nov, 2015.

[23] Balali M.H., Nouri N., Nasiri A.and Seifoddini H., "Development of an Economical Model for a Hybrid System of Grid, PV and Energy Storage Systems", 4th International Conference on Renewable Energy Research and Applications, Palermo, Italy, 22-25 Nov 2015.

[24] Bansal M., Dhillon J. and Virmani R., "Development of operation strategy for a solar PVCAES based system in market scenario", Second International Conference on Computational Intelligence \& Communication Technology, pp. 362-365, 2016.

[25] Luo X., Wang J., Dooner M. and Clarke J., "Overview of current development in electrical energy storage technologies and the application potential in power system operation", Applied Energy, Volume 137, pp. 511-536, 1 January 2015.

[26] Taylor J. and Halnes A., "Analysis of compressed air energy storage," PCIC Europe 2010, Oslo, pp. 1-5., 2010. de Biasi V., "New solutions for energy storage and smart grid load management". Gas Turbine World. Vol. 39, No. 2, pg. 455460, April 2009.

[28] Xinjing Z., Haisheng C., Jinchao L., Wen L. and Chunqing $\mathrm{T}$., "Research progress in compressed air energy storage system: A review", Energy Storage Science and Technology, Vol.1, Issue1, pg.26-40, 2012.

[29] Ghaljehei M. and Golkar M.A., "Effect of optimal generation scheduling of compressed air energy storage and wind power generation on economic and technical issues", Smart Grid Conference (SGC), Issues, pp. 1-6. 2017.

[30] Li N., and Hedman K.W., "Economic Assessment of Energy Storage in Systems with High Levels of Renewable Resources", IEEE Transactions on Sustainable Energy, Vol. 6, No. 3, pp. 11031111, 01.07.2015.

[31] Vollaroa R.D., Fagaa F., Tallinib A., Vallatic L.C.A., "Energy and thermodynamical study of a small innovative compressed air energy storage system (micro-CAES)" ATI 2015 70th Conference of the ATI Engineering Association, pp. 645 - 651, 2015.

[32] Setiawan A., Priyadi A., Pujiantara M. and Purnomo M.H., "Sizing compressed-air energy storage tanks for solar home systems," 2015 IEEE International Conference on Computational Intelligence and Virtual Environments for Measurement Systems and Applications (CIVEMSA), Shenzhen, pp. 1-4, 2015.

[33] Kamran M., Bilal M. and Zaib Z., "LabVIEW Based Simulator for Solar Cell Characteristics and MPPT Under Varying Atmospheric Conditions", Mehran University Research Journal of Engineering and Technology, Vol. 37, No. 3, 529-538 July 2018.

[34] Ibrahim H., llinca A. and Perron J., "Energy storage systems-Characteristics and comparisons", Renewable and Sustainable Energy Reviews, Volume 12, Issue 5, June 2008, pp. 1221-1250.

[35] Hill C.A., Such M.C., Chen D., Gonzalez J.and Grady W.M., "Battery Energy Storage for Enabling Integration of Distributed Solar Power Generation, "IEEE Transactions on Smart Grid, Vol. 3, no. 2, pp. 850-857, June 2012.

[36] Rampurkar S., Sandhu K.S. and Kumar R., "Performance of parallel connected 
Compressed Air Energy Storage for proper utilization of Wind Energy", International Conference on Advances in Mechanical, Industrial, Automation and Management Systems (AMIAMS), pp. 285-270, 2017.

[37] Salgi G. and Lund H., "System behaviour of compressed-air energy-storage in Denmark with a high penetration of renewable energy sources", Applied Energy, Vol. 85, Issue 4, pp. 182-189, April 2008.

[38] Yuan C.Y., Zhang T., Rangarajan A., Dornfeld D., Ziemba B.and Whitbeck R., "A decision-based analysis of compressed air usage patterns in automotive manufacturing "Journal of Manufacturing Systems, Vol. 25, Issue 4, 2006, Pages 293-300.

[39] Giraud F. and Salameh Z. M., "Steady-state performance of a grid-connected rooftop hybrid wind-photovotaic power system with battery storage, "IEEE Transactions on Energy Conversion, Vol. 16, no. 1, pp. 1-7, March 2001.

[40] Mahmoudi I.R.H., "The control strategy for a hybrid wind-photovoltaic system with compressed air storage element", 2nd International Conference on Electrical and Information Technologies ICEIT, pp. 89-92, 2016.
[41] Rauf S., Wahab A., Rizwan M., Rasool S., Khan N., "Application of Dc- Grid for efficient use of PV System in Smart Grid", The 6th International Conference on Sustainable Energy Information Technology (SEIT 2016), Procedia Computer Science, 83-2016, pp. $902-906$.

[42] Moallemi A., Machado L., Koury R.N.N. and Pujatti F.J.P., "The Effect of Energy Efficiency Increase on a PV Plant with a Non-Conventional Energy Storage System Income", 7th Power Electronics, Drive Systems and Technologies Conference (PEDSTC 2016), Iran University of Science and Technology, Tehran, Iran, pp. 457-463, Feb 2016.

[43] Rizzo V.M.G. and Tiano F., "Application of dynamic programming to the optimal management of a hybrid power plant with wind turbines, photovoltaic panels and compressed air energy storage", Applied Energy Vol. 97 (C), pp. 849-859, September 2012.

[44] Hsiao Y-T, and Chen C-H, "Maximum power tracking for photovoltaic power system," Conference Record of the 2002 IEEE Industry Applications Conference, 37th IAS Annual Meeting, Pittsburgh, PA, USA, pp. 1035-1040, Vol.2, 2002. 